\title{
FINANCIAL RISKS AND PERFORMANCE OF LISTED MANUFACTURING FIRMS IN NIGERIA
}

https://doi.org/10.47743/jopafl-2021-22-11

\author{
Tonia Yetunde AYENI \\ Department of Banking and Finance, Afe Babalola University, \\ Ado-Ekiti, Nigeria \\ akindutireyt@abuad.edu.ng \\ ORCID: https://orcid.org/0000-0003-1727-8538
}

\author{
Helen Oluyemisi EMEKA \\ Department of Mathematical and Physical Sciences, Afe Babalola University, \\ Ado-Ekiti, Nigeria, \\ emekaho@abuad.edu.ng
}

\begin{abstract}
The recent economic issues in Nigeria have necessitated the identification of elements that contribute to the country's underwhelming performance. However, factors like unstable foreign exchange rate, rising inflation rate and insecurity has been studied at macroeconomic level while little attention has been given to factors like financial risks and how they have an influence on the functioning of manufacturing firms. This study therefore, investigated the effect of financial risks on the performance of manufacturing firms in Nigeria. Data were sourced from the annual financial statements of manufacturing firms that are listed on the Nigerian Stock Exchange for the period 2010 to 2020. Panel regression technique based on fixed effect model was employed to establish the effect of leverage risk, liquidity risk, firm size and age of firm on return on asset. It was discovered that leverage risk, liquidity risk, firm size have adverse and significant effect on return on asset while age of firm has positive and insignificant effect on return on asset. Financial risk of manufacturing sector in Nigeria is on the rise, especially as a result of debt and increase in current liabilities over current assets which are constraints on general performance. It is recommended that manufacturing firms should avoid incurring excessive debt in order to avoid increase the risk of leverage. In addition, effective strategies should be employed to monitor and manage financial risks in order to reduce or eliminate the negative consequences of these risks.
\end{abstract}

Keywords: Financial risk, performance, return on asset, leverage risk, liquidity risk

\section{Introduction}

The business environment of a company is surrounded by diverse factors which influence operational and financial performance. Thus the business decision of organizations relies on many factors in which financial and operational risks have continued to be given greater attention by managers and investors. According to Jafari, Chadegani and Biglari (2011); White and Frame (2004), firms face the problems of risk which result from technology changes, complex environment, high competition, regulatory challenges and other issues amongst others. Risk, which is regarded as the possibility of deviations in the changes of expected outcomes or returns, have gain prominence in the field of financial management and corporate finance in the recent years (Bansal Robert, Robert \& Edward, 1992; Holton, 2004). Risks is believed to determine the investment decisions and future prospects of an organization and a manager is constantly devising means to reduce risks of financial loss and business winding up. According to Arif and 
Showket (2015); Fali, Terzungwe and Mustapha (2020), financial risk is the possibility of collapse when there is high debt in the financial composition of firm's capital structure with low cash balance.

The issue of financial risk and other risks have received wide attention given the recent problem of global financial crisis, credit crunch and unexpected business fluctuations. Hence, managers adopts different techniques to eliminate financial risks while trying to maximize return (Fang, 2016). The management of financial and other risks have been difficult and this has been made more pronounce due to global rapid changes and financial failures that are experienced in the recent years (Carlson, 2006; Lewis, 2010). In this regards, the achievement of higher performance in the presence of financial and operational risks may be difficult when there is lack of effective strategies (Stanley, 2013). The manufacturing sector is seen as one of the major facilitator of economic growth in the modern era. In developed and developing countries like China, Germany, Japan, Malaysia and South Africa among others, manufacturing sector has been used to achieve industrial transformation and development. The sector is germane in the growth process and has contributed immensely to an economy in terms of employment and income distribution.

In Nigeria, the recent challenges in the economy has resulted in the need to identify factors that contribute to the country's underwhelming performance. However, while factors like unstable exchange rate, rising inflation and insecurity rates are studied at macroeconomic level, factors like financial and operational factors have received little attention at firms' level (Offiong, Udoka \& Bassey, 2019). In the recent years, the challenges faced by the Nigerian manufacturing sector is enormous and the need to resuscitate the sector as one of the driver of growth has resulted in the need to investigate the factors that influence manufacturing sector performance. However, few studies focused on the effect of financial risks on manufacturing sector performance in Nigeria. Most of these studies focused on the effect of risk management on performance. This study, therefore, investigates the effect of financial risks on the performance of manufacturing firms in Nigeria. Following the introduction, the other part of the paper are sectionalised into literature review, methodology, discussion and analysis of data, conclusion and recommendations.

\section{Literature Review}

Theoretically, it is suggested that direct relationship is expected between risks and return of firms (Puspitaningtyas, 2017). However, effective risk management have been identified to have the capacity to help reduce or eliminate risks that are associated with investments and business decisions while maximizing returns (Otekunrin, Eluyela, Nwanji, Faye, Howell \& Tolu-Bolaji, 2021). According to Offiong, et al., (2019) inability to managed risk effectively may result in poor performance and consequent business failure. Thus, management are periodically monitoring the level of financial and other components of risks while devising means to manage and reduce them.

Jafari, et al., (2011) analysed the linkage between risk management and performance of companies from 2003 to 2008. They discovered that risk management had positive and significant effect on the performance of companies. Through the adoption of multiple regression and descriptive techniques, Wangalwa and Muturi (2018) examined how operational risk affects supermarket performance in Nairobi County. Operational risk 
was found to have a negative impact on asset return in the study. Sisay (2017) in his study $\mathrm{x}$-rayed the implication of the impact of financial risk on the financial performance of Ethiopian insurance companies. Secondary sources and unstructured in-depth interviews were used to collect data. The panel regression results revealed that credit risk, liquidity risk, and solvency risk all had a negative and significant impact on insurance firm profitability. Nyasaka (2017) studied the impact of credit risk on non-performing loans at Kenyan banks, with a special focus on the KCB group, was explored. Data was collected from 100 respondents at headquarters and branch offices and evaluated using an inferential technique. Credit risk has a considerable impact on non-performing loans, according to the study.

The study of Alshubiri (2015) was conducted to analyze the impact of financial and business risks on Oman's industrial sector performance. The research was conducted from 2009 to 2013 by obtaining data from 47 firms listed on the Muscat Security Market (MSM) in Oman. The study employed mixture of simple regression, multiple regression and multiple regression techniques to analyzed data. The research found that financial and business risk had a significant impact on the industry's performance. Puspitaningtyas (2017) studied the effect of financial information on the systematic risk of manufacturing firms in Indonesia. The study collected data from companies that are listed on Indonesia Stock Exchange from 2011 to 2015. Data were analysed with simple regression technique and it was revealed that financial leverage, liquidity, and profitability had insignificant effects on systematic risk.

Offiong, et al., (2019) investigated the effect of financial risk on the performance of SMEs, the study covered the period of 1986 to 2017 by sourcing data from Central Bank of Nigeria (CBN) statistical bulletin. Autoregressive distributed lag (ARDL) technique was used to analyse the data and it was discovered that there is In the long run, there is a negative and insignificant relationship between financial risk and SMEs' performance in Nigeria. Exchange currency risk, liquidity risk, interest rate risk, and inflation risk all have a significant and negative impact on small and medium firms in the short and long term, according to the study. Onsongo, Muathe and Mwangi (2020) explored the effect of financial risk on the performance of listed companies in Nairobi Securities Exchange (NSE). The study covered the period of 2013 to 2017 and was analysed with panel regression technique. The study revealed that credit risk positively and insignificantly influence return on equity, liquidity risk negatively and significantly influence ROE while operational risk positively and insignificantly influence ROE. Otekunrin, et al., (2021) adopted panel data technique to investigate the effect of enterprise risk management on the performance of listed manufacturing firms in Nigeria. Data were collected from the financial statements of thirty listed manufacturing companies over 2010 to 2018 and enterprise risk management was determined to have a significant impact on the performance of listed manufacturing firms in Nigeria.

\section{Methodology}

This study explored the effect of financial reforms on the performance of manufacturing firms in Nigeria. The study adopted ex post facto research design because the data are historical and quantitative in nature with the aim of investigating the direction of relationship among them. Data were sourced from secondary means specifically from 
the financial statement of listed manufacturing firms on the Nigerian Stock Exchange Market from 2012 to 2020.

\section{Model Specification}

The investigation of the relationship between financial risk and shareholders' value is modeled based on panel regression model. The model is adapted from the empirical study of Osongo (2020) wherein return on equity was modeled as a function of credit risks, liquidity risk and operational risk. By modification, this study focused mainly on financial risk by employing leverage and liquidity risks while firm size and age of the firms were taken as control variables. Thus, the model for the study is given as:

$R O A=f(L E V R, L R, F M S, A G E)$

Thus, the model is econometrically given as:

$\mathrm{ROA}_{i \mathrm{t}}=\beta_{0}+\beta_{1} \mathrm{LEVR}_{\mathrm{i}}+\beta_{2} \mathrm{LR}_{\mathrm{i}}+\beta_{3} \mathrm{FMS}_{\mathrm{i}}+\beta_{4} \mathrm{AGE}_{\mathrm{i}}+\mathrm{e}_{1 \mathrm{i}}$

Where:

RAO $=$ Return on Asset

LEVR = Leverage Risk

LR = Liquidity Risk

$\mathrm{e}=$ error term

$\mathrm{t}=$ time series variable

$$
\begin{gathered}
\text { FMS }=\text { Firm Size } \\
\text { AGE }=\text { Age } \\
\mathrm{i}=\text { cross-sectional variable }
\end{gathered}
$$

\section{Method of Data Analysis}

Descriptive statistics is used to describe the characteristics of the data series while correlation matrix was employed to determine the direction of relationship among the variables. Furthermore, panel regression technique was adopted to establish the effect of leverage risk, liquidity risk, firm size and age of firm on return on asset. However, fixed effect panel regression and random effect panel regression, The Hausman test was employed to select the best suited technique between fixed effect panel regression and random effect panel regression.

\section{Results and Discussion}

\section{Descriptive Analysis}

The descriptive statistical analysis of the data employed are presented in Table 1. The result shows that age of firms and firms' size have the highest mean values followed by return on assets. In addition, the minimum value of -7.765140 for return on asset shows that some of the maneuvering companies are operating at loss. The result further reveals that return on asset and firm size are negatively skewed while leverage risk liquidity risk and age of firms are positively skewed. It was shown as also that the data series are mixture of leptokurtic, platykurtic and mesokurtic. 
Table 1: Descriptive Statistic

\begin{tabular}{|c|c|c|c|c|c|}
\hline & ROA & LEVR & LR & FMS & AGE \\
\hline Mean & 11.93858 & 4.751429 & 1.206433 & 24.27040 & 66.24242 \\
\hline Maximum & 28.57245 & 6.794956 & 2.939759 & 26.67059 & 142.0000 \\
\hline Minimum & -7.765140 & 3.109271 & 0.226992 & 19.28239 & 21.00000 \\
\hline Skewness & -0.057189 & 0.005012 & 0.961028 & -1.519598 & 0.578987 \\
\hline Kurtosis & 2.509417 & 3.083888 & 3.765798 & 5.356406 & 2.937407 \\
\hline
\end{tabular}

Source: Author's Computation, 2021

\section{Correlation Analysis}

Table 2 presents the correlation matrix for the variables used in the study. The study shows that there is evidence of absence of multi co-linearity among the variables. The result further shows that leverage risk, liquidity ratio and firms size have negative and weak correlation with return on asset: their correlation coefficients are $-0.15,-0.05$ and -0.25 respectively. However, the result shows that age of firms has positive and weak movement with return on asset with a coefficient of 0.086648 .

Table 2: Correlation Matrix

\begin{tabular}{|c|c|c|c|c|c|}
\hline & ROA & LEVR & LR & FMS & AGE \\
\hline ROA & 1.000000 & & & & \\
\hline LEVR & -0.148316 & 1.000000 & & & \\
\hline LR & -0.055658 & -0.580964 & 1.000000 & & \\
\hline FMS & -0.251006 & 0.312148 & -0.160957 & 1.000000 & \\
\hline AGE & 0.086648 & -0.222426 & 0.092115 & 0.267449 & 1.000000 \\
\hline
\end{tabular}

Source: Author's Computation, 2021

\section{Hausman Test}

Table 3: Hausman Test

\begin{tabular}{|c|c|c|c|}
\hline Test Summary & Chi-Sq. Statistic & Chi-Sq. d.f. & Prob. \\
\hline Period random & 12.398646 & 4 & 0.0146 \\
\hline
\end{tabular}

Source: Author's Computation, 2021

From table 4 , the chi-square $\left(x^{\wedge} 2\right)$ with probability value of 0.0146 is statistically significant at 5\% significance level. This implies that the fixed effect model produces an unbiased estimate compared to the random effect model. The fixed effect recreation is therefore considered fitting and reported in the study.

Table 4: Diagnostic Test

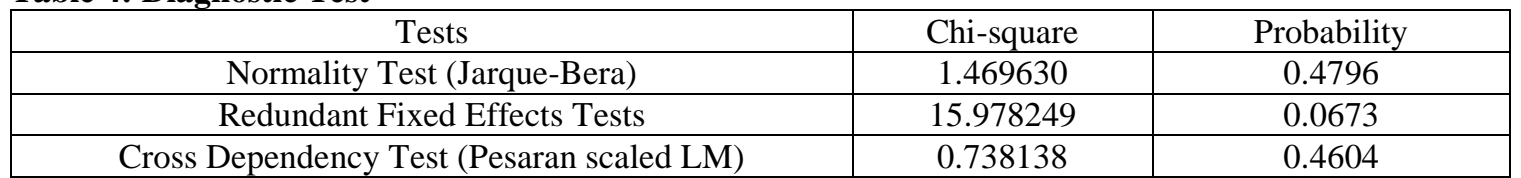

Source: Author's Computation, 2021

Table 5 reports the diagnostic test for the estimated fixed regression model and it indicates that model residual is normally distributed with a probability value of 0.4796 which is greater than the acceptance region of 0.05. Also, the result shows the absence of redundant fixed effects in the residual of the regression. Finally, the result shows absence 
of cross dependency in the regression residual given Peasaran scaled LM probability of 0.4604 which is greater that the acceptance region of 0.05 .

Fixed Regression Analysis

Table 5: Fixed Effect Regression Result

Dependent Variable: Return on Asset

\begin{tabular}{|c|c|c|c|c|}
\hline Variable & Coefficient & Std. Error & t-Statistic & Prob. \\
\hline LEV & -2.336512 & 1.048048 & -2.229394 & 0.0284 \\
\hline LR & -3.799243 & 1.334143 & -2.847702 & 0.0055 \\
\hline FMS & -1.045458 & 0.522255 & -2.001815 & 0.0485 \\
\hline AGE & 0.028225 & 0.020828 & 1.355132 & 0.1790 \\
\hline C & 51.12789 & 12.89602 & 3.964624 & 0.0002 \\
\hline
\end{tabular}

F-statistic $=2.139920$

Probability Value $=0.019434$

Source: Author's Computation, 2021

The result reported in Table 5 shows the fixed regression on the effect of leverage risk, liquidity risk, firm size and age on return on asset. The result shows that leverage risk has negative and significant effect on the return on asset of listed manufacturing firms in Nigeria with a coefficient of -2.336512 . This implies that $1 \%$ increase in leverage risk will lead to $2.3 \%$ fall in the return on asset of listed manufacturing firms in Nigeria. The implication of this findings is that the adoption of leverage risk will impose risk on the financial position of manufacturing firms which will lead to fall in performance. This indicates that over-leverage risk will bring about risk of debt and interest payment which would impose constraints on the financial performance of firms. This is not in line with findings of Alshubiri (2015). Also, the result reveals liquidity ratio has a coefficient of 3.799243 which is significant at $5 \%$. This suggests that $1 \%$ increase in liquidity risk will lead to $3.8 \%$ fall in return on asset of manufacturing firms. This indicates that the selected listed manufacturing firms are facing liquidity crisis such that current assets fell short of current liabilities. This result conforms to the findings of Offiong, et al., (2019); Asongo, et al., (2020).

In addition, the control variable firms' size is found to have negative and significant effect on return on asset with a coefficients of -1.045458 which implies that $1 \%$ increase in firms size will lead to $1 \%$ fall in the return on asset of listed manufacturing firms in Nigeria. This points to the underutilisation of assets of manufacturing firms in Nigeria which has imposed constraints on the financial performance of firms. This findings however does not conformed with the result of Puspitaningtyas (2017) but corroborates the result of Otekunrin, et al., (2021). However, age of firms is found to have positive but insignificant effect on return on asset with a coefficient of 0.028225 . Finally, the result shows that the independent variables, namely leverage risk, liquidity risk, firm size and age have joint and significant effect on return on asset with an F-statistic and probability values of 2.139920 and 0.019434 respectively which are significant at 5\%. 


\section{Conclusion and Recommendations}

This study was conducted to analyse the effect of financial risk on the performance of listed manufacturing firms in Nigeria. The study covered the periods of 2010 to 2020 based on secondary data from the annual financial statement of listed manufacturing firms on the Nigerian Stock Exchange. Data were analysed with fixed effect regression model. The study found that the components of leverage and liquidity risks have negative and significant effect on return on assets of listed manufacturing firms in Nigeria. Also, the control variable, firm size have negative and significant effect on return on assets while age of firm has positive but insignificant effect on return on assets. This findings point to the rising financial risk of manufacturing sector in Nigeria especially in the area of overusage of debt and increasing current liabilities over currents assets. These have implications on the performance of firms with falling return on assets.

It is therefore, concluded that the performance of manufacturing is constrained by financial risks which requires adequate management. It is recommended that manufacturing firms should avoid excessive debts in the capital structure combination because it increases the risk of leverage. Furthermore, adequate attention should be given to liquidity position of firms by manager. Firms should work effectively on reducing excess current liabilities through timely settlement of liabilities. Managers should come up with effective strategies for the monitoring and management of financial risks in order to reduce or eliminate the negative consequences.

\section{References}

1. Alshubir, F. (2015). Measurement the impact of financial and business risk on performance: Evidence of industrial sector of Oman. Asian Social Science, 11(22), 26-32. http://dx.doi.org/10.5539/ass.v11n22p26

2. Arif, A., \& Showket, A. (2015). Relationship between financial risk and financial performance: An Insight of Indian Insurance Industry. International Journal of Science and Research, 4,1424-33. https://ssrn.com/abstract $=3553374$

3. Bansal, A., Robert, K., Robert. M., \& Edward, P. (1992). Financial risk and financial risk management technology: Issues and Advantages. Working Papers Series; New York: New York University. 4. Carlson, M. (2006). A brief history of the 1987 stock market crash. Finance and Economics Discussion Series. Divisions of Research \& Statistics and Monetary Affairs, Federal Reserve Board, Washington, D.C. http://www.federalreserve.gov/pubs/feds/2007/200713/200713pap.pdf

5. Fali, I., Terzungwe, N., \& Mustapha, O. L. (2020). Financial risk and financial performance of listed insurance companies in Nigeria. European Journal of Business and Management, 12, 143-53.

6. Fang, F. (2016). A study of financial risks of listed manufacturing companies in China. Journal of Financial Risk Management, 5, 229-245. http://dx.doi.org/10.4236/jfrm.2016.54022

7. Holton, G. A. (2004). Defining risk. Financial Analysts Journal, 60, 19-25. https://doi.org/10.2469/faj.v60.n6.2669

8. Jafari, Chadegani and Biglari (2011). Effective risk management and company's performance: Investment in innovations and intellectual capital using behavioral and practical approach. Journal of Economics and International Finance, 315), 780-786, https://doi.org/10.5897/JEIF11.123

9. Lupu, D. (2019). Financial development and economic growth in Eastern Europe. Journal of Public Administration, Finance and Law, (16), 157-165.

10. Nyasaka, F. (2017). The relationship between credit risk management practices and non- performing loans in Kenyan commercial banks: A Case Study of KCB Group Limited. Master's thesis, United States International University—Africa, Nairobi, Kenya. Unpublished. 
11. Offiong, A. I., Udoka, C. O., \& Bassey, J. G. (2019). Financial risk and performance of small and medium enterprises in Nigeria. Investment Management and Financial Innovations, 16(4), 110-122. https://doi.org/10.21511/imfi.16(4).2019.10

12. Onsongo, S. K., Muathe, S. M. A., \& Mwangi, L. W. (2020). Financial risk and financial performance: evidence and insights from commercial and services listed companies in Nairobi Securities Exchange, Kenya. International Journal of Financial Studies, 8(51), 1-15. https://doi.org/10.3390/ijfs8030051

13. Otekunrin, A. O., Eluyela, D. F., Nwanji, T. I., Faye, S., Howell, E. K., \& Tolu-Bolaji, J. (2021). Enterprise risk management and firm's performance: A study of listed manufacturing firms in Nigeria. Research in World Economy, 12(1), 32-41.

14. Puspitaningtyas, A. (2017). Estimating systematic risk for the best investment decisions on manufacturing company in Indonesia. Investment Management and Financial Innovations, 14(1), 46-54.

15. Sisay, D. (2017). The effect of financial risk on performance of insurance companies in Ethiopia. Ph.D. thesis, Addis Ababa University, Addis Ababa, Ethiopia. Unpublished.

16. Stanley, M. (2013). Impact investing. morganstanleyfa.com/public/projectfiles/d76aaa84-beac4296-aad2-00786b56493e.pdf

17. Wangalwa, M., \& Muturi, W. (2018). Effect of financial risk on financial performance of largescale supermarkets in Nairobi County, Kenya. International Journal of Social Science and Technology, 4, 574-91.

18. White. L. J., \& Frame, W. S. (2004). Emerging competition and risk-taking incentives at Fannie Mae and Freddie Mac. Working paper. New York: New York University - Leonard N. Stern School of Business Creative Commons Attribution - Non Commercial - No Derivatives 4.0 International License. 